\title{
Ouyang Jianghe's Aesthetic Principles in their Relation to the Modern Poetic Tradition in Russia
}

\author{
Sofiia Zaichenko \\ Faculty of Oriental Studies, Department of Eastern Languages and Literatures, \\ Ankara University
}

Received: 02-02-2015

Accepted: 02-03- 2015

Published: 01-04- 2015

doi:10.7575/aiac.ijclts.v.3n.2p.32

URL: http://dx.doi.org/10.7575/aiac.ijclts.v.3n.2p.32

\begin{abstract}
This article presents a comparative analysis of the modern Chinese and Russian poetry. Peculiar linguo-philosophical ideas of an internationally recognized Chinese poet Ouyang Jianghe are being juxtaposed with poetic views of famous Russian poets such as Osip Mandelstam, Joseph Brodsky and Arkadii Dragomoshchenko. The paper should be of interest to readers, because it deals with the yet unexplored topic. Recently, scholars have focused on the relationship between Chinese and Russian poetry of the classical period. According to a generally accepted opinion, the dialogue between Russian and Chinese literary traditions does not move further than the classical masterpieces by Dostoevsky, Pushkin, Gogol, Turgenev and Tolstoy. Hypothesis of research - a creative interaction between Russian and Chinese literatures still goes on after the collapse of the Soviet Union, which has lead to the loosening of strong cultural ties between Russia and China. As a proof of this statement the present paper reveals striking similarities between the theories of the Acmeist Mandelstam and the leading post-Obscure poet Ouyang Jianghe. That is, both of them share the language-centered approach to the art of poetry. Secondly, this paper provides factual evidence that Heidegger's view on language as the house of being is one the main features uniting poetry of Dragomoshchenko, Brodsky and Ouyang. In summary, Russian school of poetry has left such a deep imprint on Chinese poetry that it can still be seen in the works of Post-Obscure poets. This article helps strengthen the intercultural dialogue, enhances mutual understanding between Russia and China and encourages further research regarding modern Chinese and Russian poetic traditions.
\end{abstract}

Keywords: word, vivifying power, dissection, Hellenism, Acropolis, hunger, house of being, readability

In the Gospel, sent to us by John, Is the saying, that the Word is God... ... And like bees in empty hives smell badly -

Badly smell the dead forever words.

Nikolay Gumilev (Note i)

\section{Introduction}

In order to find points of intersection between the two seemingly parallel roads (Russian and Chinese poetry) let's take an internationally-acclaimed Chinese poet Ouyang Jianghe (欧阳江河) as a starting point. The literary movement he represents has various names including "New Generation" (xin shengdai 新生代), “Experimental Poetry" (shixian shi 实验诗) and "post-Obscure Poetry" (hou menglong shi 后朦胧诗). First of all, let us mention the fact that contemporary Chinese poets are well acquainted with Osip Mandelstam, Anna Akhmatova, Marina Tsvetayeva, Nikolai Gumilev and Boris Pasternak whose brilliant works make up the Silver Age of Russian poetry. Ouyang is not an exception, either. Remarkably, he refers to Mandelstam as "the spirit-nourishing poet" ("Russian literature has nourished our spirit", 2006) who has exerted a considerable influence upon himself and his contemporaries. What kind of influence has the above-mentioned Russian poet had on Ouyang Jianghe?

\subsection{Mandelstam's Conception of "the Word as Such" and its Implementation in Ouyang's Poetry}

To begin with, Mandelstam is known as a leading figure in the Acmeist movement famous for paying attention to the word as such. This conception has initially been put forward by Russian Futurists who treat words as mere sounds free from meaning. In Mandelstam's poetics, however, the word per se (1993: 178) is embodied in flesh. It has its own heartbeat. Therefore, it gains weight becoming heavy like a stone. In other words, by comparing the word to a stone, he raises a rather complicated and peculiar issue on the interplay between word and material object, sensible thing. The question is: How does all this relate to post-Obscure Poetry? In order not to sound proofless let us provide a quote from Wang Chenlong's (王辰龙) article: “One can say that Ouyang Jianghe's works echo Mandelstam's concept of a 'living poetry of the word-object'. Such a concept vigorously opposes to the ideas expressed by Symbolists, Futurists and 
Imagists" ("The narrator who transpasses objects, space and time", 2013). What he means is that both Mandelstam and Ouyang, by focusing on the word as such in its relationship with material objects, offer a new linguo-philosophical approach to the art of poetry. Additionally, Ouyang (2001: 9) likens the word to a "lamp that can be turned on, a plate that can be polished". Basically, the word gains the status of a tangible object in physical reality. In other words, it exists; it is real. Now the plot thickens: for Acmeists like Mandelstam the word by itself is what actually constitutes the reality. Put another way, the whole universe is word-centered. Ouyang, in his turn, doesn't miss the opportunity to say that people are nothing but "a bunch of spirits created by words" (2001: 90). In his poems objective and textual reality are inseparably interwoven into the whole fabric. Furthermore, the reality itself can be neither true nor false. Paper and pen are the only things that are real. That is, Ouyang becomes utterly absorbed in the so-called reality of the word. To sum up, both Mandelstam and Ouyang bid defiance to conventional poetry. Their linguistic experiments expand far beyond boundaries of traditional versification.

\section{2 "The Handgun Effect” - Ouyang's Manifesto against Clichéd Conventionality}

Whereas in Symbolism, Imagism and Chinese Obscure Poetry the center of gravity lies in the word's nominative power, in Acmeism it is shifted to a life-giving vivifying power of words (Kikhney, 2003: 67). The main idea is that the word is no more a servant of poets' obscure ideas. That is to say, every word, apart from simply naming objects, also breathes new life into these objects rescuing them from obscurity. Admittedly, the above-discussed Mandelstam's expression "living poetry" makes much more sense after considering all these facts. In a similar way, Ouyang talks about the poetry which by using words' power revives objects and lets them breathe; poetry that leaves a sense of materiality, physicality. Consequently, there is no place left for spiritless abstraction. What is even more important is that every word-object needs to be actually touched and chewed upon by the poet. The metaphor of chewing signifies an endless process of regeneration and recreation of meanings. More precisely put, the author not only gives us a sense of words' materiality and corporeality, but also puts forward a manifesto against numb, hardened and deadened images; clichéd expressions. At issue here is the question: How does this manifesto get implemented in Ouyang's poetry? To begin with, according to the poet himself, every material object is somewhat similar to a handgun (shouqiang 手枪). That is to say, every object can be disassembled, taken apart. Such a process inevitably results in the splitting of reality, creation of alternative poetic realities. Besides, a process of gun disassembly strikingly resembles dissection of a Chinese character (chaizi 拆字). In other words, Ouyang applies the same principle to the word as such. As a result, one gets a feeling that the whole world cracks down just as the word is thoroughly analyzed, dissected, taken apart and put back together in a new way. The character itself falls apart. Figuratively speaking, when the old skin is peeled off, layers of new meanings can grow in their place. From this viewing standpoint, one can easily draw a parallel between Ouyang and Futurist Velimir Khlebnikov who "busied himself with words like a mole digging down into the earth to make a path into the future for the entire century" (Polukhina, 2008: 295).

\section{3 "Domestic Hellenism” as an Antidote for Utilitarian Approach to Language}

Both Mandelstam and Ouyang advocate for the pure aesthetic approach which implies vigorous opposition to utilitarianism in language. Unlike conventional understanding, the word is no more an ideological instrument. It is no more just a means of communication. It becomes a real solid body - alive and embodied in flesh. By the way, such an idea of corporeality, materiality and physicalness of words is reflected in linguistic experiments conducted by Dadaists and Futurists. Hugo Ball (1996: 221), for instance, states that "words emerge, shoulders of words, legs, arms, hands of words". Khlebnikov (1989: 57), in his turn, initiates us into a secret: "He taught me words you can see with (eyewords) and words you can do with (handwords)". Actually, parts of human body, upper and lower extremities are often brought into play by Futurists. However, as mentioned in the Section 1.1., body of the word in their understanding is purely sound, acoustic. That is, Khlebnikov's poem consists of chopped-up body parts which are of no significance in their own right. They are meaningless and therefore dependant. In order to support this statement let's remember Mandelstam's (1993: 178) words: "If in Futurism word as such still crawls on all fours, in Acmeism it - for the first time - adopts a more worthy upright position". And in Symbolism everything has gone to the opposite extreme: things, material objects have no freedom whatsoever. The reason is that these objects are hopelessly captivated by tons of sentimentally flavored comparisons and ponderous, labored associations. We live in the era of conception thinking, era of estrangement. According to Mandelstam, images are disemboweled and filled with a different content. Therefore, we are steadily moving away from the thing per se into an impenetrable darkness of metaphors. A brilliant philosopher Walter Benjamin substantiates Mandelstam's point of view by saying that "warmth is ebbing from the things" (Gilloch, 2002: 74). And Ouyang Jianghe in the poem entitled "Glass Factory" seems fully aware of this fact. Quite logically, in his poem he talks about the fire that doesn't give warmth any more. The poet doesn't want things, material objects to freeze readers to death, so he makes a determined effort to restore their body temperature. Figuratively speaking, he seals up gaps and holes so that cold air can't enter the world of poetry. As a result, one gets a peculiar sense of comfort and coziness. This is Ouyang's version of what Rob-Griye has once called chosisme. Put more specifically, Chinese poet surrounds himself with living objects instead of hollow images. By doing this, he signifies a return of the long-lost world order where even the smallest thing is spirit-filled. Based on these observations, we can draw another parallel between Russian and Chinese poetic traditions. That is, Mandelstam also emphasizes on a necessity of "warming of the surrounding world with the most delicate teleological warmth" (Mandelstam, Monas, 1975: 516). The point is that such warmth can only be drawn from domestic utensils. Since ancient Greeks have treated every word-object as a live, breathing and warm flesh, Russian poet chooses to call this literary phenomenon "domestic Hellenism". Additionally, his point of view is that Symbolists are still tinkering with dead, numb and lifeless shades. Thus, they go against the word's Hellenistic nature. Quite the contrary, both Acmeists and Ouyang surround themselves with these so-called 
domestic utensils. So, Ouyang's expression "a lamp that can be turned on, a plate that can be polished" will come in handy at this point. It is kind of a challenge to cold void and cultural vacuum. Objects seem to be supporting poets in their heated debates with non-existence. Since the debate is won, a new life is injected into poetry, making blood flow more swiftly through its veins. Consequently, a struggle against non-existence is a sacred duty of every word-object.

\subsection{Reflection of Mandelstam's “Word as an Acropolis" in Ouyang's Poetry}

Modernist as these two poets are, their works are nevertheless based on a rather traditional culture-centered approach. This is what distinguishes Acmeists and post-Obscure poets from Futurists who totally reject tradition and culture as such. Put another way, neither Futurists nor Symbolists accept Hellenistic interpretation of the word as an active flesh, a rational being. And yet Mandelstam goes on to develop his idea further. He calls the word a "small Acropolis", history keeper, "slim body of the culture" (Kikhney, 2003: 68). According to him, the word as such possesses a cultural memory which, in its turn, serves as a guarantee of cultural continuity and immortality. Besides, the word's life-giving vivifying power inhales fresh air into Russian language reviving it. Eventually, language itself turns into the "ringing and speaking flesh" (Mandelstam, O., Monas, S., 1975: 510). Generally speaking, the word becomes the spirit of Russian culture. Put another way, there can be no culture without language, and there can be no language without a breathing poetic word. Once again, we have come close to the point where Russian and Chinese poetic traditions intersect. That is, Ouyang Jianghe in the poem entitled “Between Chinese and English” (han ying zhijian 汉英之间) presents his vision of a word (character) as a living, perceptible, full-blooded living body: "Some arms, legs, eyes fall away, but words still move on, stretch out, and see" (Ouyang, 2013b: 20). Thus, he aims at showing how great the potential hidden within Chinese characters really is. There is just one problem: a character's body is falling apart before our very eyes. By drawing such a picture, Ouyang probably implies a rather painful process of simplification of Chinese characters. That is, traditional characters fall apart becoming simplified. Basically, this phrase is the way to express his deep concern about Chinese culture which he sees as decaying. Put more specifically, Chinese nation is being deprived of traditional characters which are keepers of the cultural wisdom. Therefore, such a nation risks sinking into oblivion. Figuratively speaking, Ouyang fears that merciless modernity (accompanied by globalization and assimilation) might hunt down and flay alive language which is the quintessence of the culture. Chinese nation seems to have lost a pristine knowledge containing in the traditional characters. The formerly strong ties between an individual and national culture are inevitably loosening. So, the most important question remains open: Can the potential for decay be reduced?

\subsection{The Point of Intersection of Ouyang Jianghe's Poetics and Futurist Manifestos}

Similarly, Mandelstam's works are also filled with an awareness of the approaching crisis. Mandelstam's (1973: 9) keen insight will surely substantiate this argument: "The word shares the fate of bread and flesh: suffering. People are hungry... But there is something hungrier yet - time". According to him, the word is our spiritual bread. And as it goes stale hunger gradually arises from hearts of people resulting in widespread cultural starvation. No wonder, the metaphor of wheat is a recurring theme throughout his poetry. Figuratively speaking, wheat has stopped growing, so the new era of hunger has begun. Now, let's give Ouyang Jianghe a chance to express his views upon this subject. He manifests a crisis of the modern society by using the following phrases: "It left behind many delicious days, let me and my race eat them; "Teeth sink into an open space"; "I finished eating my portion of days, then ate the ancients"” (Ouyang, 2013b: 20). On the one hand, Ouyang is criticizing Chinese people who are - with complacent confidence and obsession feeding on the remains of the ancients. They have sucked all the blood from ancient language. They have eaten all the characters' flesh. So, a stuffed museum specimen is the only thing remaining after such a linguistic feast. Don't these observations bring to mind Mandelstam's remark about images disemboweled like stuffed animals? Based on these observations, we can conclude that the contemporary art feels deep hunger for development, cultural progress. Put another way, language experiences stagnation. In fact, the reason for it lies in fixation, unwillingness to move forward or make changes. What has initially been supposed to be an antidote to the toxicities of modernity turns out to be the poison itself. No wonder, Ouyang admits to have seen piles of Chinese characters become corpses. Once again, he condemns those carried away with a blind imitation of the ancients. Let's emphasize that the object of Ouyang's criticism is not the traditional culture itself, but the arrogant overly obsessive attitude towards it. Apparently, this is one of the reasons why he offers to let Symbolists like Bei Dao (北岛), Yang Lian (杨炼), Gu Cheng (顾城) and Shu Ting (舒婷) become a thing of the past (Ouyang, 2013a). From this standpoint Ouyang Jianghe's ideas can be compared to the ones expressed by Russian Futurists. Both Futurist Khlebnikov and Ouyang to some extent bid defiance to tradition. Khlebnikov is much more radical, though. He is the rioter on the ship of Russian poetry: "Throw Pushkin, Dostoevsky, Tolstoy, etc. overboard from the Ship of Modernity” (Burliuk, Kruchenykh..., 2005: 51).

\section{6 "Language of the Leopard" in its Correlation with the Hellenistic Principle of "Inner Freedom"}

On the other hand, Ouyang in "Our Sleep, Our Hunger" (women de shuimian, women de ji e 我们的睡眠, 我们的饥饿) talks about a “leopard's hunger”, that is to say, a hunger of the language itself. Basically, Chinese language feels hungry, because it has been put in a virtual cage, ideological prison. The author also likens words to hungry dogs ready to bite with all their might. In other words, Ouyang expresses a sincere concern for his native language being used as an ideological means. According to him, Chinese language possesses the same features leopard does: vigorous, full of energy and freedom-loving. Of course, this leopard has the full right to freedom. Quite logically, being deprived from this right, leopard strives to break walls of that ideological cage and escape. This is where leopard's hunger arises from. Similarly to a leopard, Chinese language also feels hunger for an unrestricted wild freedom. The poet, in his turn, feels hunger for a pure aesthetics. Wolfgang Kubin's (2012) statement will prove these assumptions: "Chinese language has turned into a vehicle for propaganda, be it politically since 1949 or economically 
since 1992". This can be interpreted as an attempt to release Chinese language from fetters imposed on it by the ideology. Besides, our Technocratic Age sends language into exile, banishes it. So, in order to revive bygone spirit of Chinese language and restore its former power, Ouyang advocates for "the language of the leopard" (bao de yuyan 豹的语言) as opposed to “the language of mice" (laoshu de yuyan 老鼠的语言). Based on this information, we can make a conclusion that both Russian and Chinese poet share the same approach to language. Put more specifically, the above-discussed powerful and energetic "language of the leopard" bears a striking similarity to Mandelstam's assumption according to which some peculiar sense of "inner freedom" (Mandesltam, Monas, 1975: 511), a free spirit is inherent in Russian language. Remarkably, this sense is exactly what unites Russian and Hellenistic literary traditions. Furthermore, in the same article Kubin adds that "besides being endangered by politics and economics, Chinese is also endangered by English. As English becomes fashionable, Chinese are increasingly abandoning their own language for a foreign tongue". What he means here is that foreign language intervenes into the holy of the holies - Chinese culture. As a result of such an intervention, Chinese nation is gradually being driven out from its home. It is no longer master in its own house. As it is widely acknowledged, every nation needs a spiritual dwelling place. No wonder, confusion, perplexity, nostalgia, craving for comfort and family warmth is read between the lines of Ouyang's poems. Additionally, he is constantly questioning himself. Where is the right path to the spiritual home of Chinese culture? Mandelstam, in his turn, admits: "We have no Acropolis. Even today our culture is still wandering and not finding its walls" (Mandesltam, Monas, 1975: 516). Here comes another feature uniting Mandelstam and Ouyang's poetics. Both of them seem to be seeking shelter in language. Spirit of the nation has lost its dwelling place, so the main task of every poet is to search for it. Figuratively speaking, a house of being is powdered with dust. According to Mandelstam, ancient Greece is a cure for the ailments of modern society, model of a true community in the disrupted age, a Third Renessaince for Russian culture. Once again, Acmeism aims at reviving Russian language, turning it into a ringing and speaking flesh. But not only Russia seeks for cultural revival. Similarly, Ouyang views Chinese language as an Acropolis during the crisis of modern consciousness. According to him, traditional characters act as an antidote for the poison modern Chinese language is overfilled with.

\section{Dragomoshchenko's Poetics as an Embodiment of Heidegger's Linguo-Philosophy}

Taking into account the previous paragraph, we can draw another parallel between contemporary Russian and Chinese poetic traditions. To start with, let's take a glance at the road taken by Russian Metarealist poet Arkadii Dragomoshchenko. His works are closely related with American Language Poetry which, in its turn, is deeply rooted in Russian philological tradition - Formalism and OPOJAZ movement. Besides, this Russian Metarealist poet has been deeply influenced by Jacques Derrida's concept of the world as text. These two factors explain why Dragomoshchenko's poems are filled with a so-called philological metaphor. Actually, such a philological, linguophilosophical approach to poetry is exactly what brings Mandelstam, Ouyang and this Russian Metarealist poet together. Philology, however, is neither a science nor a mere occupation. Quite the contrary, it is viewed upon as an entrance ticket to the dwelling of being - language. Generally speaking, in their understanding poetry is all about language. Moreover, Ian Probstein (2013) notices that Dragomoshchenko is a deeply existentialist poet, which is manifested to the full in his efforts to explore the web of being. According to Dragomoshchenko, being itself is a text. Therefore, language of poetry is the only way to read this text, that is to say, to decode and explore the being. In order not to sound proofless he quotes the leading figure of Language Poetry Lyn Hejinian (2000: 3): "The language of poetry is a language of inquiry, not the language of a genre". Next, Probstein in the poem entitled "Elegy. In memoriam of Arkadii Dragomoshchenko" uses phrases such as "the words touch being"; "returning into the Word which was in the Beginning". It's worth mentioning that the idea of language as a living creature, a vivifying word is deeply engrained in Christian tradition. That is to say, the Gospel of John tells us that "In the beginning was the Word, and the Word was with God, and the Word was God... The Word became flesh and made his dwelling among us" (Note ii). Similarly, the language per se becomes a backbone, frame work, foundation stone of Dragomoshchenko's poems. Figuratively speaking, Russian language allows poet to touch the untouchable - being. At this point it becomes clear why various scholars find similarities between Dragomoshchenko's poetics and Martin Heidegger's philosophical approach to language: "Language is the house of Being. In its home man dwells" (2008: 217). Put another way, words dwell in the language which is the house of being. To sum up, Dragomoshchenko's poetics is an embodiment of Heidegger's linguophilosophical views.

\subsection{Mandelstam, Ouyang, Brodsky and Dragomoshchenko - House-of-Being-Keepers}

Now, let us return to Ouyang Jianghe's poetry. Obviously, his image of "home" has a strong bent for Heidegger's idea of language as a house of being: "I reside in a pile of character parts"; "I live alone secluded in Chinese". Similarly to Dragomoshchenko and Heidegger, Ouyang turns out to be a house-of-being-keeper. Therefore, as soon as this house is ruined, the poet immediately falls into cultural vacuum. This is where feelings of perpetual loneliness and inner solitude come from. Taking into consideration this information, let's mention Joseph Brodsky who expresses similar ideas towards language and also cultivates philological metaphor. Apparently, Ouyang's phrase "I live alone secluded in Chinese" correlates with Brodsky's idea that every poet is sooner or later left tete-a-tete with the language. But the fact is that the poet is always doomed to loneliness to one degree or another (Volkov, 2002: 137). To sum up, language is the only homeland to Brodsky, Dragomoshchenko, Mandelstam and Ouyang Jianghe. Furthermore, the above-discussed sense of escapism and asceticism isn't alien to poetics of Arkadii Dragomoshchenko and the whole Metarealist movement in general. That is to say, artistic devices used by these poets also result in aesthetic alienation, estrangement from the reality. Basically, their poetry can be referred to as a forced escapism into the field of "pure aesthetics" (Golynko-Volfson, 2003). Obviously, escapism of Ouyang and Dragomoshchenko is a protest against social reality of 
the 1980-1990s; reality full of ideological garbage, dust and clichés. Besides, both poets are renowned for their rejection of mainstream in literature and resorting to linguistic experiments. They use the so-called language of inquiry in order to explore the house of being.

\subsection{Ouyang's Challenge to Readability. Poetic Eye as a Camera.}

Next, Lyn Hejinian (2000: 330) in the collection of essays entitled "The Language of Inquiry" states that "the fact of modern poetry's being "hard to read" can be extolled as a virtue in and of itself". Remarkably, such an unreadability is widely accepted to be one of the main distinctive features of Dragomoshchenko's poetry. Now, let's point out another two common features that unite the poetry of Ouyang and Dragomoshchenko and therefore contribute to the intercultural dialogue between Chinese and Russian poetic traditions. Firstly, Ouyang shares Hejinian and Dragomoshchenko's innovative approach towards reading poetry. That is, this Post-Obscure poet sees unreadability as a quite natural phenomenon of modern times. His point of view is that every worthwhile poem should actually be a challenge to readability. Poetry doesn't necessarily need to be understood. Sometimes it just leaves reader with a "sense of language" (Ouyang Jianghe, 2013a). Doesn't this metaphor correlate with what Mikhail Iampol'skii (2000) has once called a "poetics of touch"? Put more specifically, Iampol'skii refers to Dragomoshchenko's language as to the one that gently touches objects leaving a reader only a pale shadow of meaning. In short, neither Dragomoshchenko nor Ouyang bothers about being understood. Quite the contrary, they leave a reader enough space for guesswork and creativity. It seems that their poems slightly touch the boundaries of language, that is to say, barely make contact with it. Secondly, Chinese poet emphasizes on a necessity for a poet's eye to turn into a camera because of its ability to seize up the right moments. According to Ouyang, this is the only way to shoot objects in motion, capture fast-vanishing images. Now it's worth mentioning that the art of photography also plays a crucial role in shaping of Dragomoshchenko's aesthetic universe. Similarly to Ouyang, he resorts to the language of photography in order to enrich his poetic metaphor (Suhovey, 2012).

\section{Conclusion}

This article deals with the influence of Russian poetic tradition on modern and contemporary Chinese poetry. It intends to loosen up the rigidity of conventional notion according to which interaction between these two literary traditions is limited to a dozen of classical masterpieces and third-rate odes to communist regime. Having analyzed the main factors contributing to this intercultural dialogue, present paper concludes that both Russian and Chinese poets adopt a rather peculiar linguo-philosophical approach to the art of poetry. In order for the issue to be efficiently illuminated, the Acmeist idea of "the word as such" and its drastic influence upon Ouyang Jianghe's poetics have been investigated. From this standpoint much attention has been paid to Mandelstam's notion of the "living word" and the way it is implemented in Ouyang's poetry. Next, current research provides evidence that both Mandelstam and Ouyang challenge the conventional view of a word as a mere instrument present in the works of Futurists and Symbolists. Additional evidence in support of continuous interaction between Russian and Chinese traditions is the fact that these two poets share a traditional culture-centered approach to language. That is to say, Mandelstam sees the word per se as a "small Acropolis" which possesses cultural memory and serves as a guarantee of cultural immortality. Ouyang, in his turn, firmly believes that a traditional character is itself the spirit of Chinese culture. Moreover, recurrence of the metaphor of hunger indicates poets' deep awareness of the crisis of modern society. In order to additionally substantiate the hypothesis formulated in the beginning of the paper, the author has clarified and expanded upon Ouyang's "language of the leopard" in its correlation with Mandelstam's principle of "inner freedom" inherent in Russian language. In the second section of this paper Heidegger's view upon language as the house of Being has been juxtaposed with the linguo-philosophical ideas of Mandelstam, Ouyang, Russian Metarealist Arkadii Dragomoshchenko and existentialist Joseph Brodsky. Finally, another two common features that unite poetry of Ouyang and Dragomoshchenko and therefore contribute to the intercultural dialogue between Chinese and Russian poetic traditions have been analyzed. That is, the concept of "unreadability" and the language of photography play an important role in shaping of these poets' aesthetic universe. In order to present a comprehensive comparative analysis, this paper has touched upon several disciplines: translation studies, comparative linguistics and linguo-culturology. Such an interdisciplinary approach has provided favorable conditions for disclosure and systematization of common features uniting modern Russian and Chinese poetic traditions.

\section{Acknowledgements}

I would like to dedicate this paper to Professor Liu Wenfei (刘文飞) whose keen insight into Chinese-Russian literary relations has laid a solid foundation for me to build upon.

\section{References}

Ball, H. (1996). Dada Manifesto. In J. Elderfield (Ed.), Flight out of time: a Dada diary. Oakland, California: University of California Press.

Burliuk, D., Kruchenykh, A., Mayakovsky, V., Khlevnikov, V. (2005). A Slap in the Face of Public Taste. In Anna Lawton and Herbert Eagle (Trans. and Eds), Words in Revolution: Russian Futurist Manifestos 1912-1928 (51). Washington DC: New Academia Publishing.

Gilloch, G. (2002). Walter Benjamin: Critical Constellations. (1st ed.). Cambridge, UK: Polity. 
Golynko-Volfson, Dmitry. (2003). Ot pustoti real'nosti k polnote metafory ["From the Emptiness of Reality to the Fullness of Metaphor"], Novoe Literaturnoe Obozrenie, 62. [Online] Available: http://magazines.russ.ru/nlo/2003/62/golviol.html

Gumilev, N. (2000). The Word. Trans. by Yevgeny Bonver. Ed. by Dmitry Karshtedt. Poetry Lovers' Page. [Online] Available: http://www.poetryloverspage.com/poets/gumilev/word.html

Heidegger, M. (2008). Basic Writings from Being and Time to The Task of Thinking. (D. F. Krell, Ed.). New York: HarperCollins.

Hejinian, L. (2000). Introduction. In L. Hejinian, The Language of Inquiry. Oakland, California: University of California Press.

Iampol'skii, M. (2000). Poetika kasania [“Poetics of Touch"]. In A. Dragomoshchenko, Opisaniie ["Description”], (pp.355-378). Saint Petersburg: Gumanitarnaia Akademia.

Khlebnikov, V. (1989). Ka. İn R. Vroon (Ed.), Collected Woks of Velimir Khlebnikov: Prose, Plays and Supersagas (Vol. 2.). Trans. by Paul Schmidt. Cambridge, Massachusetts: Harvard University Press.

Kikhney, L.G. (2003). "Korrel'atsyia "Slova" i "Veshchi” v Akmeisticheskoi traditsiyi" ["Correlation of the "Word" and "Object" in the Acmeist tradition"]. Postsymbolism as a Cultural Phenomenon, 4, 67-71.

Kubin, W. (2012, January). Wolfgang Kubin on Ouyang Jianghe. Asymptote. (Adapted from Ouyang Jianghe. (2012). Doubled Shadows: Selected Poetry of Ouyang Jianghe. Trans. by Austin Woerner. Brookline, MA: Zephyr Press). [Online] Available: http://www.asymptotejournal.com/article.php?cat=Special_Feature\&id=49\&curr_index=21\&curPage=

Mandelstam, O. (1973). Complete Poetry of Osip Emilevich Mandelstam. Albany, New York: State University of New York Press.

Mandelstam, O., Monas, S. (1975). Osip Mandelstam: About the Nature of the Word. Arion: A Journal of Humanities and the Classics, New Series, 2 (4), 506-526. http://dx.doi.org/10.2307/i20163389

Mandelstam, O. (1993). Utro Akmeizma [“Morning of the Acmeism”]. In Collection of works in four volumes (Vol. 1., pp. 178). Moscow, Russia: Art-Bisness-Centre.

Ouyang Jianghe 欧阳江河. (2001). “站在虚构这边” [“Standing on the side of fabrication”]. Hong Kong, China: Joint Publishing.

Ouyang Jianghe. (2013a, March 24). “欧阳江河：让北岛、杨炼、顾城、舒婷成为往事吧” “"Let Bei Dao, Yu Lian, Gu Cheng, Shu Ting become a thing of the past”]. Yangcheng Wanbao.

Ouyang J. (2013b). 如此博学的饥饿：欧阳江河集 [“Such a learned hunger: Collection of Works by Ouyang Jianghe"]. Beijing, China: Zuojia chubanshe.

Polukhina, V. (2008). Brodsky Through the Eyes of His Contemporaries. Studies in Russian and Slavic Literatures, Cultures, and History. (2nd ed.). Boston: Academic Studies Press.

Probstein, I. (2013). Reputacyia: Pam'ati Arkadiia Dragomoshchenko [“Reputation: In Memoriam to Arkadii Dragomoshchenko"]. Gvideon, 5.

Suhovey, D. (2012). Saphirovskiie chtenia- 2011 [“Saphirov Readings- 2011”]. RGGU, Moscow, 17-18 November 2011. Novoe Literaturnoe Obozrenie, 118.

The Holy Bible, King James Version. Cambridge Edition: 1769. King James Bible Online, 2015. http://www.kingjamesbibleonline.org/.

Volkov, S. (2002). Conversations with Joseph Brodsky: A Poets Journey Through The Twentieth Century. New York: The Free Press.

Wang Chenlong 王辰龙. (2013). 穿越事物与时空的善谈者一欧阳江河论 [“The Narrator who transpasses objects, space and time- Ouyang Jianghe"]. Xin Wenxue Pinglun, 3. [Online] Available: http://www.poemlife.com/libshow3087.htm

俄罗斯文学滋润过我们的心灵[“Russian literature has nourished our spirit”]. (2006, September 6). Xinjingbao. [Online] Available: http://www.gmw.cn/content/2006-09/01/content_473771.htm

\section{Notes}

i. For the full version of the poem, see Nikolay Gumilev: “The Word.” Poetry Lovers' Page, Last modified December, 2000 .

ii. For more information, see John 1:1, 1:14. King James Version (KJV). 